\title{
Application of Nanotextured Carbons for Electrochemical Energy Storage in Aqueous Medium
}

\author{
François Béguin
}

\author{
CRMD, CNRS-University, IB rue de la Férollerie, 45071 Orléans Cedex 02, France
}

\begin{abstract}
Este trabalho apresenta um capacitor híbrido, com dois eletrodos diferentes trabalhando em seus intervalos de potencial ótimos. O eletrodo negativo é baseado na sorção reversível de hidrogênio, que ocorre em valores baixos de potencial em carbono com nanoporos. Ciclos galvanostáticos no intervalo de temperatura entre 20 e $60{ }^{\circ} \mathrm{C}$ demonstram que o hidrogênio é fracamente quimi-sorvido. Isto é confirmado por medidas de TPD (de-sorção em temperatura programada) no material do eletrodo após carga, que mostram um pico devido ao hidrogênio, em 200-250 ${ }^{\circ} \mathrm{C}$. O eletrodo positivo é um composto feito de nanotubos de carbono, como componente minoritário, e $\mathrm{MnO}_{2}$. Propriedades interessantes são obtidas na presença de nanotubos, tais como desenvolvimento de porosidade, alta condutividade elétrica e uma boa elasticidade, o que acentua o poder e o ciclo de vida dos supercapacitores. O capacitor híbrido é capaz de operar em valores altos de voltagem, $2 \mathrm{~V}$ em meio aquoso, com um ciclo de vida longo.
\end{abstract}

This paper presents a hybrid capacitor, with two different electrodes working in their optimal potential range. The negative electrode is based on the reversible hydrogen sorption which occurs at low potential values in nanoporous carbons. Galvanostatic cycling at temperatures ranging from 20 to $60{ }^{\circ} \mathrm{C}$ demonstrates that hydrogen is weakly chemisorbed. This is confirmed by TPD on the electrode material after charging, which shows a peak due to hydrogen at 200$250{ }^{\circ} \mathrm{C}$. The positive electrode is a composite made of carbon nanotubes, as minor component, and $\mathrm{MnO}_{2}$. Interesting properties are given by the presence of nanotubes, such as a developed porosity, a high electrical conductivity and a good resiliency, all being very important for enhancing the power and cycle life of supercapacitors. The hybrid capacitor is able to operate at voltage values as high as $2 \mathrm{~V}$ in aqueous medium with a long cycle life.

Keywords: nanotextured carbons, energy storage, hybrid supercapacitor

\section{Introduction}

Efficient electrochemical energy storage is an important challenge for a number of applications, including mobile phones, computers, electric vehicles, cordless tools, ... Among the various devices available, supercapacitors, also called electrochemical capacitors, ${ }^{1}$ are recently the object of a great interest for the high power pulses which they are able to provide. However, the deliverable energy density of supercapacitors is generally too small, imposing performance improvements.

The energy of a supercapacitor is given by the classical equation (1):

$E=1 / 2 C V^{2}$

*e-mail: beguin@cnrs-orleans.fr where $C$ is the capacitance and $V$ the operating voltage. The voltage is determined by the stability window of the electrolyte. For symmetric capacitors working in aqueous medium, $V$ is generally of the order of $0.6-0.7 \mathrm{~V}$. Values of 2.3-2.5 V can be reached in organic electrolytes, but these media are less environment friendly than water, as they often contain harmful solvents, e.g., acetonitrile. The capacitance itself is determined by the charge storage mechanism. In the electrical double layer capacitors (EDLCs), the charge is stored in the electrical double layer which forms at each electrode. The capacitance of one electrode, $\mathrm{C}_{\mathrm{e}}$, is given by the equation (2):

$\mathrm{C}_{\mathrm{e}}=\varepsilon \mathrm{S} / \mathrm{d}$

where $S$ represents the surface area of the electrode/ electrolyte interface and $d$ the thickness of the electrical 
double layer. Due to their high specific surface area, good electrical conductivity and low cost, activated carbons are used as electrode materials of EDLCs. ${ }^{2}$ Although some studies are under progress for better understanding the relationship between the capacitance values and the textural parameters of porous carbons, it is now recognized that drastic increase of capacitance will not be possible with these materials. By contrast, a second class of capacitors, called pseudo-capacitors, seems to be the most attractive for the new perspectives of breakthrough which they offer. In this case, quick redox reactions are at the origin of the storage mechanism, and the charge transferred is proportional to voltage. ${ }^{2}$ This phenomenon called pseudo-capacitance is observed in aqueous medium with conducting polymers, ${ }^{3,4}$ transition metal oxides $\left(\mathrm{RuO}_{2}\right.$, $\left.\mathrm{MnO}_{2}, \ldots\right)^{5,6}$ and heteroatom enriched carbons. ${ }^{7,8}$

In this paper, we present a hybrid capacitor which operates at $2 \mathrm{~V}$ in aqueous medium with a good cyclability, using two different materials working in their optimal potential range at each electrode. ${ }^{9}$ The negative electrode is based on the reversible hydrogen sorption properties of nanoporous carbons. ${ }^{10}$ For the positive electrode, nanotubes are used as support of $\mathrm{MnO}_{2}{ }^{6}$ Interesting properties are given by the presence of nanotubes, such as a developed porosity, a high electrical conductivity and a good resiliency, all being very important for enhancing the power and cycle life of supercapacitors. The following presentation will be divided in two parts, giving first information on the state of hydrogen electrochemically stored in carbon and then considering the hybrid construction itself.

\section{Experimental Sets}

\subsection{Electrochemical hydrogen storage}

Electrochemical hydrogen storage was investigated using a three-electrode cell in $6 \mathrm{~mol} \mathrm{~L}^{-1} \mathrm{KOH}$, where the working electrode is a self-standing activated carbon cloth (ACC), prepared from viscose fibers (type I isotherm, $\mathrm{S}_{\mathrm{BET}}=1390 \mathrm{~m}^{2} \mathrm{~g}^{-1}$ ). Nickel is used as counter electrode and $\mathrm{Hg} / \mathrm{HgO}$ is the reference $(+0.098 \mathrm{~V}$ vs. NHE). For a full saturation of the samples by hydrogen, the galvanostatic charging process is carried out with a great excess of charge, that is possible by using a current of $-500 \mathrm{~mA} \mathrm{~g}^{-1}$, as explained elsewhere. ${ }^{10}$ Due to the extreme charging conditions, the high overvoltage increases the kinetics of hydrogen formation, thus increasing the kinetics of its sorption on the carbon surface. The reversible hydrogen uptake is evaluated from the faradaic charge consumed for the hydrogen oxidation process with a current load of $25-50 \mathrm{~mA} \mathrm{~g}^{-1}$. Hydrogen storage efficiency with temperature is studied by galvanostatic charge/discharge and voltammetry between 20 and $60{ }^{\circ} \mathrm{C}$.

Hydrogen loaded in the carbon cloth was analyzed by temperature-programmed desorption (TPD). After a galvanostatic charge during a given time, the cloth is extracted from the electrochemical cell, then degassed at $100{ }^{\circ} \mathrm{C}$ under vacuum until physisorbed water is completely eliminated, and temperature is increased with a ramp of $5^{\circ} \mathrm{C} \min ^{-1}$ up to $950{ }^{\circ} \mathrm{C}$, while the hydrogen desorption rate is analyzed on-line by mass spectrometry at $m / z=2$. The total amount of hydrogen evolved during the heat treatment is calculated by integration of the desorption curve. ${ }^{11}$

\subsection{Hybrid capacitor associating activated carbon and a-MnO $\mathrm{O}_{2} / \mathrm{CNTS}$ electrodes in aqueous medium}

CNTs (a quantity corresponding to 15 wt.\% in the final composite) were added to a $\mathrm{KMnO}_{4}$ aqueous solution and stirred vigorously in order to obtain a homogeneous mixture. The amorphous manganese oxide/carbon nanotubes $\left(a-\mathrm{MnO}_{2} \cdot \mathrm{nH}_{2} \mathrm{O} / \mathrm{CNTs}\right)$ composite is precipitated by mixing the previous solution with a $\mathrm{Mn}(\mathrm{OAc})_{2} \cdot 4 \mathrm{H}_{2} \mathrm{O}$ solution. ${ }^{12,13}$ After filtration, the composite is thoroughly washed with deionized water and dried at $120{ }^{\circ} \mathrm{C}$ during 12 hours. For comparison purpose, composites were also prepared by the same process, using carbon black instead of nanotubes.

The $a-\mathrm{MnO}_{2} / \mathrm{CNTs}$ composite or an activated carbon powder (ACP - Maxsorb, Kansai, Japan) were mixed with Teflon ${ }^{\circledR}(10 \%)$ as binder, and pressed to form $1 \mathrm{~cm}^{2}$ electrodes. Two-electrode Swagelok ${ }^{\circledR}$ cells were built with gold current collectors and glassy fibrous separator between the pellet electrodes. For the three-electrode cells, a Pt wire and $\mathrm{Hg} / \mathrm{Hg}_{2} \mathrm{SO}_{4}$ are used as counter and reference electrodes, respectively. In both cases, the electrolyte is a $2 \mathrm{~mol} \mathrm{~L}^{-1} \mathrm{KNO}_{3}$ aqueous solution.

\subsection{Electrochemical techniques}

Cyclic voltammetry and galvanostatic charge/ discharge cycling were performed using a VMP multichannel potentiostat-galvanostat (Biologic, France). A VMP2 (Biologic-France) was used for the impedance spectroscopy measurements. An ac amplitude of $20 \mathrm{mV}$ is applied to reach the steady-state cell voltage, and the data are collected in the range of $10,000 \mathrm{~Hz}$ to $0.001 \mathrm{~Hz}$. 


\section{Results and Discussion}

\subsection{Electrochemical hydrogen storage}

In alkaline solution, water is electrochemically reduced by the carbon electrode according to equation (3):

$\mathrm{H}_{2} \mathrm{O}+\mathrm{e}^{-} \rightarrow \mathrm{H}+\mathrm{OH}^{-}$

The nascent hydrogen formed in (3) is partly fixed on the nanopores surface as in equation (4):

$<\mathrm{C}>+\mathrm{xH} \rightarrow<\mathrm{CH}_{\mathrm{x}}>$

whereas another part may recombine to form $\mathrm{H}_{2}$ molecules. Equation (5) summarizes the two processes:

$<\mathrm{C}>+\mathrm{xH}_{2} \mathrm{O}+\mathrm{x} \mathrm{e}^{-} \leftrightarrow<\mathrm{CH}_{\mathrm{x}}>+\mathrm{xOH}^{-}$

where $\langle\mathrm{C}\rangle$ and $\left\langle\mathrm{CH}_{x}\right\rangle$ stand for the nanotextured carbon substrate and for hydrogen inserted into this substrate, respectively. During the oxidation step, the above reactions run in opposite direction.

Voltammetry curves obtained with the activated carbon cloth (ACC) in $3 \mathrm{~mol} \mathrm{~L}^{-1} \mathrm{KOH}$ are shown in Figure 1. The various loops have been recorded with $-100 \mathrm{mV}$ stepwise shift of negative potential cut-off. For electrode potentials higher than the thermodynamic value corresponding to water decomposition (theoretically $-0.856 \mathrm{~V}$ vs. NHE, i.e. $-0.908 \mathrm{~V}$ vs. $\mathrm{Hg} / \mathrm{HgO}$, in $3 \mathrm{~mol} \mathrm{~L}^{-1} \mathrm{KOH}$ ), the box-like shape of the curves confirms the reversible charging of the electrical double layer. The increase of negative current which is observed from the third loop, i.e. when the potential cut-off is lower than the equilibrium potential, is a proof that the faradaic water decomposition starts gradually to take place. As a consequence, during the anodic scan, the positive current recorded above the equilibrium potential increases, being related with the electro-oxidation of hydrogen trapped in ACC.

When the negative potential cut-off decreases, the positive current due to hydrogen oxidation increases and the corresponding hump shifts towards positive potential values (Figure 1). The high over-potential required for hydrogen oxidation reveals either a strong hydrogen trapping in the carbon material or important diffusion limitations.

The contribution of diffusion has been estimated by cyclic voltammetry at two scan rates, e.g., 1 and $5 \mathrm{mV}$ $\mathrm{s}^{-1}$, in $6 \mathrm{~mol} \mathrm{~L}^{-1} \mathrm{KOH}$ (Figure 2). In order to take into account the differences of scan rate, and for an easy comparison of the two curves, the current values obtained at $1 \mathrm{mV} \mathrm{s}^{-1}$ have been multiplied by 5 . As seen

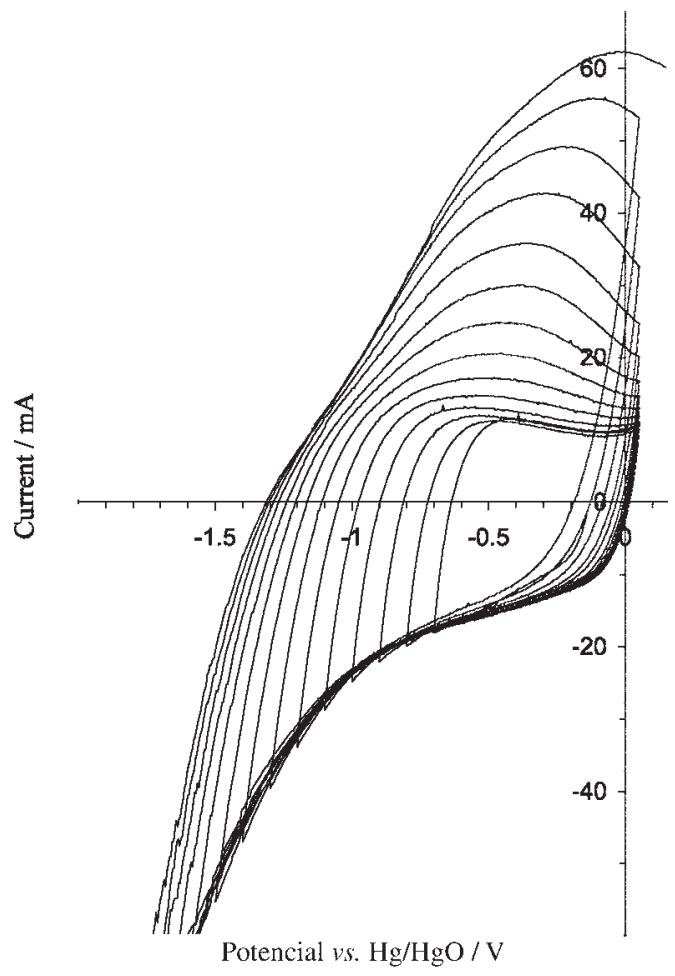

Figure 1. Voltammetry characteristics of ACC at various values of negative potential cut-off (-100 mV stepwise shift). Electrolyte: $3 \mathrm{~mol} \mathrm{~L}^{-1} \mathrm{KOH}$ Scan rate of potential: $5 \mathrm{mV} \mathrm{s}^{-1}$ (adapted from reference 10).

from Figure 2, the peak related with hydrogen oxidation is noticeably shifted to a lower potential value when the scan rate is diminished to $1 \mathrm{mV} \mathrm{s}^{-1}$. Taking into account that the electrochemical hydrogen trapping takes place essentially in ultramicropores (i.e. pores smaller than $0.7-0.8 \mathrm{~nm}),{ }^{14}$ and that tortuous voids may slow down the desorption process from these pores, one easily understands the improved tendency to reversibility at low scan rate. However, the anodic peak position observed at $1 \mathrm{mV} \mathrm{s}^{-1}$ is still higher than the hydrogen equilibrium potential in $6 \mathrm{~mol} \mathrm{~L}^{-1} \mathrm{KOH}$, e.g., - $0.874 \mathrm{~V} v s$. NHE suggesting weak chemical hydrogen bonding with the carbon surface. ${ }^{15}$

Tendency to chemical bonding of hydrogen has been confirmed by TPD analyses on ACC samples obtained after a galvanostatic charge during 15 minutes or 12 hours at $-500 \mathrm{~mA} \mathrm{~g}^{-1}$ in $6 \mathrm{~mol} \mathrm{~L}{ }^{-1} \mathrm{KOH}$ (Figure 3). In order to avoid an unwanted hydrogen desorption, the samples were not rinsed with water after the electrochemical charging. As a consequence they both present a peak above $400{ }^{\circ} \mathrm{C}$, which is due to the reaction of excess $\mathrm{KOH}$ with carbon, according to equation (6): ${ }^{16}$

$6 \mathrm{KOH}+2 \mathrm{C} \rightarrow 2 \mathrm{~K}+3 \mathrm{H}_{2}+2 \mathrm{~K}_{2} \mathrm{CO}_{3}$ 


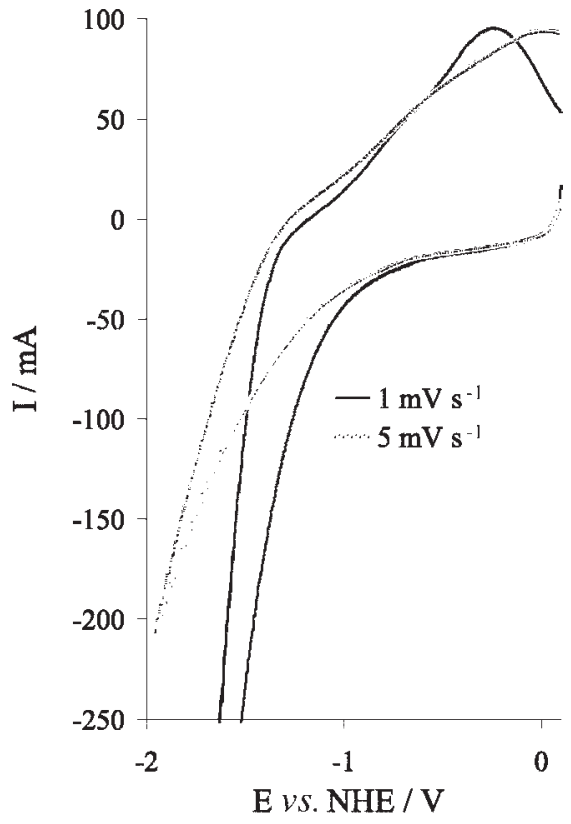

Figure 2. Influence of the scan rate $\left(1\right.$ and $\left.5 \mathrm{mV} \mathrm{s}^{-1}\right)$ on the voltammetry characteristics of ACC in $6 \mathrm{~mol} \mathrm{~L}^{-1} \mathrm{KOH}$ (adapted from reference 15).

It is the only peak observed for the sample charged 15 minutes at $-500 \mathrm{~mA} \mathrm{~g}^{-1}$. Within this limited time, the Nernst potential for water reduction is not reached, and only the electrical double layer is charged. By contrast, when charging is prolonged during 12 hours, an additional peak appears in the TPD curve around $200{ }^{\circ} \mathrm{C}$. This peak location characterizes weak chemical bonds of hydrogen with the carbon surface. Hence, it is likely that the major fraction of nascent hydrogen produced during water decomposition reacts preferentially with the dangling bonds, instead of being purely physisorbed on the surface.

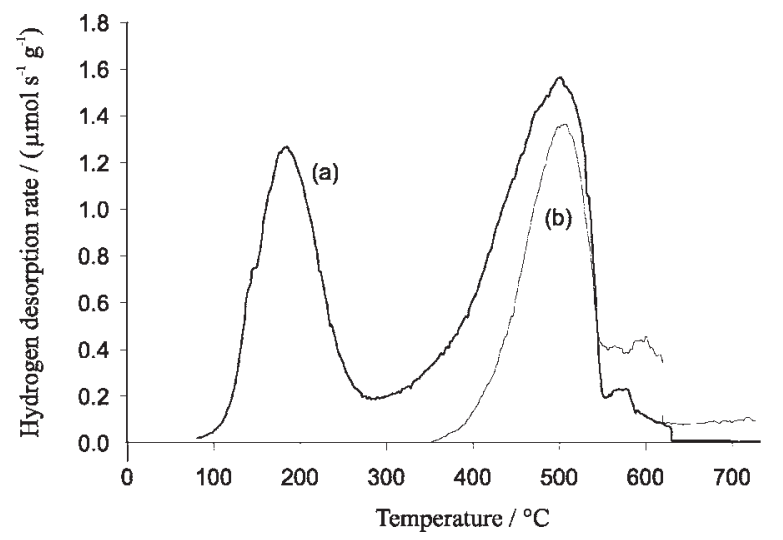

Figure 3. TPD analysis of hydrogen evolved from ACC charged galvanostatically at $-500 \mathrm{~mA} \mathrm{~g}^{-1}$ in $6 \mathrm{~mol} \mathrm{~L}^{-1} \mathrm{KOH}$ during (a) 12 hours; (b) 15 minutes (adapted from reference 15).

The nature of hydrogen bonding with ACC has been further investigated by galvanostatic charge/discharge experiments at various temperatures ranging from 20 to $60{ }^{\circ} \mathrm{C}$ (Figure 4). The increase of reversible capacity with temperature confirms that hydrogen sorption in the carbon material is activated by temperature, that proves the chemical character of the bond. Moreover, as expected for a chemisorption process, the reduction potential increases and the oxidation one decreases with increasing temperature, i.e. the kinetic barrier of sorption and desorption phenomena is reduced. ${ }^{15}$

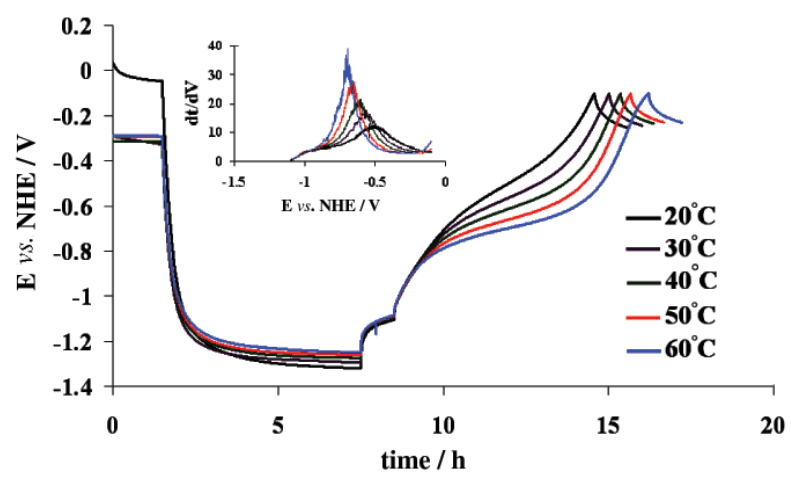

Figure 4. Effect of temperature on the galvanostatic charge/discharge of ACC in $6 \mathrm{~mol} \mathrm{~L}^{-1} \mathrm{KOH}$. Charging current $-150 \mathrm{~mA} \mathrm{~g}^{-1}$; discharging current $+50 \mathrm{~mA} \mathrm{~g}^{-1}$. Inset: derivative of the galvanostatic oxidation curves: the maximum of the derivative curves shifts from -0.5 to $-0.7 \mathrm{~V} v s \mathrm{NHE}$ as temperatures increases from 20 to $60^{\circ} \mathrm{C}$ (adapted from reference 15).

On the practical point of view, these data show that activated carbons are very interesting materials when they are used as negative electrode of an electrochemical cell in aqueous medium. In particular, when temperature is raised to $60^{\circ} \mathrm{C}$, one can remark a noticeable enhancement of the reversible capacity and a shift of oxidation potential from about -0.5 to $-0.7 \mathrm{~V} v$ s. NHE (see the shift of the derivative curve maximum - inset of Figure 4). Hence, the voltage (and consequently the energy density) of a cell using an activated carbon anode will be enhanced by operating at higher values of temperature.

\subsection{Hybrid capacitor associating activated carbon and a- $\mathrm{MnO}_{2} / \mathrm{CNTS}$ electrodes in aqueous medium}

As explained in the introduction, the performance of electrical double layer capacitors is limited by the fact that the basic phenomenon is the adsorption of ions on the pore surface. Although many attempts try to optimize the pore texture, the gain in capacitance values is very limited. A second problem originates from the small voltage value of symmetric capacitors in aqueous medium. For these reasons, taking into account the demonstrated electrochemical characteristics of activated carbon under negative polarization ${ }^{10}$ and $a-\mathrm{MnO}_{2}$ under positive polarization, ${ }^{6}$ we propose an asymmetric capacitor operating at $2 \mathrm{~V}$, based on the pseudo-capacitance properties of these two materials in aqueous medium. 
The pseudocapacitance properties of hydrous oxides are attributed to the redox exchange of protons and/or cations with the electrolyte as in equation 7 for $a-\mathrm{MnO}_{2} \cdot \mathrm{nH}_{2} \mathrm{O}:{ }^{17}$

$\mathrm{MnO}_{\mathrm{a}}(\mathrm{OH})_{\mathrm{b}}+\mathrm{nH}^{+}+\mathrm{ne}^{-} \leftrightarrow \mathrm{MnO}_{\mathrm{a}-\mathrm{n}}(\mathrm{OH})_{\mathrm{b}+\mathrm{n}}$

where $\mathrm{MnO}_{\mathrm{a}}(\mathrm{OH})_{\mathrm{b}}$ and $\mathrm{MnO}_{\mathrm{a}-\mathrm{n}}(\mathrm{OH})_{\mathrm{b}+\mathrm{n}}$ indicate interfacial $a-\mathrm{MnO}_{2} \cdot \mathrm{nH}_{2} \mathrm{O}$ in higher and lower oxidation states, respectively. However, due to the low electrical conductivity of $a-\mathrm{MnO}_{2} \cdot \mathrm{nH}_{2} \mathrm{O}$, a conducting additive is required for the realization of supercapacitor electrodes. Therefore, $a-\mathrm{MnO}_{2}$ has been precipitated on carbon nanotubes (CNTs) by adding $\mathrm{Mn}(\mathrm{OAc})_{2} \cdot 4 \mathrm{H}_{2} \mathrm{O}$ to $\mathrm{KMnO}_{4}$ solution which contained predetermined amounts of CNTs. ${ }^{6}$ The SEM picture presented in Figure 5 shows the morphological aspect of a composite charged with $15 \mathrm{wt} . \%$ of nanotubes. The striking fact is a remarkable template effect of the entangled nanotubes framework, with an extremely good adhesion of the coating layer on the carbon nanotubes. These textural characteristics are favorable

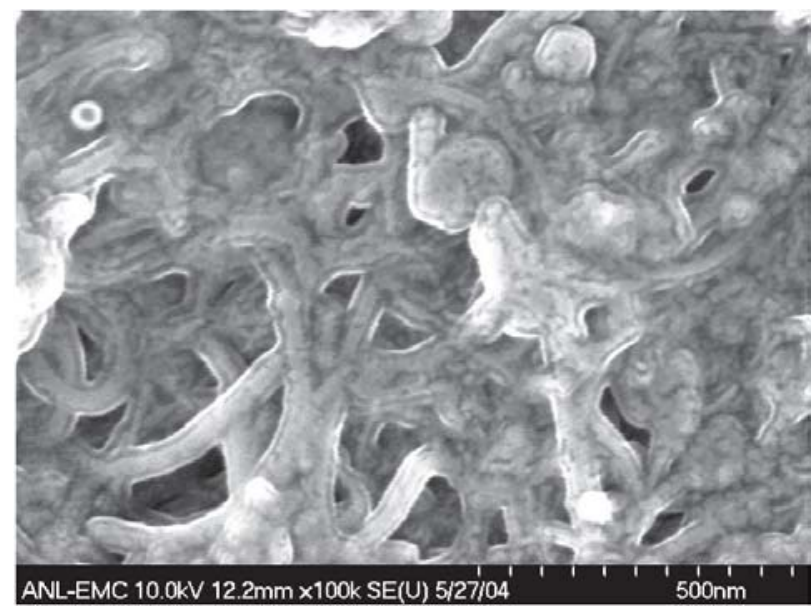

Figure 5. SEM image of the $a-\mathrm{MnO}_{2} / \mathrm{CNTs}$ composite containing $15 \mathrm{wt}$.\% of nanotubes (Courtesy of M. Thackeray, Argonne National Laboratory, USA). simultaneously for an easy access of ions to the bulk of the active material, a low electrical resistance and a good resiliency of the composite electrodes.

The values of specific capacitance and cell resistance obtained with symmetric two-electrode capacitors built with $a-\mathrm{MnO}_{2} / \mathrm{CNTs}$ composite electrodes are presented in Table 1 . The addition of nanotubes to $a-\mathrm{MnO}_{2}$ causes a drastic decrease of cell resistance and an increase of specific capacitance referred to the mass of $a-\mathrm{MnO}_{2} \cdot \mathrm{nH}_{2} \mathrm{O}$. However, when the specific capacitance is referred to the total mass of the composite electrode material, to be realistic, a carbon nanotubes loading higher than 10-15 wt.\% does not improve the electrodes performance. Therefore, $10-15 \mathrm{wt} . \%$ of CNTs conducting additive seems to be an optimal amount both on the point of view of electrodes capacitance and cell resistance.

Usually, in the battery industry, carbon black is used for the percolation of electrodes. Therefore, in order to appreciate the advantages of nanotubes, two-electrode capacitors have been built with $a-\mathrm{MnO}_{2} \cdot \mathrm{nH}_{2} \mathrm{O}$ composite electrodes loaded with 15 wt.\% of CNTs and 15 wt.\% of carbon black, respectively. The shape of the voltammetry curves presented in Figure 6 demonstrates that the capacitive behavior of $a-\mathrm{MnO}_{2} \cdot \mathrm{nH}_{2} \mathrm{O}$ is remarkably improved when CNTs are used instead of carbon black for the realization of the composite electrodes. Moreover, the values of equivalent series resistance (ESR) are 4 and $50 \Omega \mathrm{cm}^{2}$ for electrodes loaded with nanotubes and carbon black, respectively, showing that nanotubes are very interesting for the development of high power pseudocapacitors with $a-\mathrm{MnO}_{2}$ as active material.

In a symmetric capacitor, the working potential of the positive and negative electrodes cannot be controlled. For this reason, the working voltage of a two-electrode capacitor based on $a-\mathrm{MnO}_{2}$ electrodes must be limited to $0.6 \mathrm{~V}$ in order to avoid the irreversible transformation of $\mathrm{Mn}(\mathrm{IV})$ into $\mathrm{Mn}$ (II) at the negative electrode. ${ }^{6}$ Therefore, we suggest to realize a hybrid system in which $a-\mathrm{MnO}_{2}$ is

Table 1. Cell resistance and specific capacitance in $1 \mathrm{~mol} \mathrm{~L}^{-1} \mathrm{Na}_{2} \mathrm{SO}_{4}$ medium for $a-\mathrm{MnO}_{2}$ loaded with different weight percentages of carbon nanotubes (from reference 6)

\begin{tabular}{lccc}
\hline $\begin{array}{l}\text { CNTs loading / } \\
(\text { wt.\% })\end{array}$ & $\begin{array}{c}\text { Specific capacitance / } \\
\left(\mathrm{F} \mathrm{g}^{-1} \text { composite }\right.\end{array}$ & $\begin{array}{c}\text { Specific capacitance / } \\
\left(\mathrm{F} \mathrm{g}^{-1}{ }_{\text {oxide }}\right)\end{array}$ & $\begin{array}{c}\text { Cell resistance / } \\
\left(\Omega \mathrm{cm}^{2}\right)\end{array}$ \\
\hline 0 & 0.1 & 0.1 & 2000 \\
5 & 19 & 20 & 625 \\
10 & 137 & 154 & 5.2 \\
15 & 137 & 161 & 4.0 \\
20 & 139 & 174 & 3.8 \\
25 & 141 & 188 & 3.5 \\
30 & 138 & 197 & 3.0 \\
40 & 140 & 234 & 2.7 \\
50 & 138 & 277 & 2.5 \\
100 & 20 & - & 2.0 \\
\hline
\end{tabular}




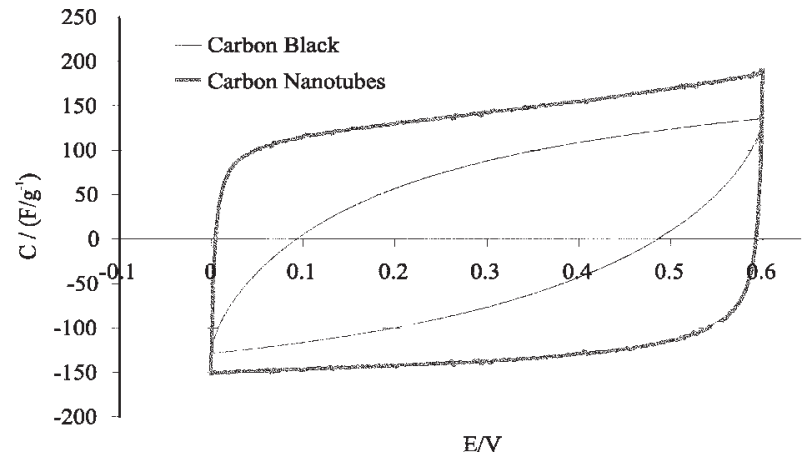

Figure 6. Comparative voltammograms of two electrode cells built with $a-\mathrm{MnO}_{2} /$ carbon black and $a-\mathrm{MnO}_{2} / \mathrm{CNTs}$ electrodes, respectively. Carbon black or CNTs loading: 15 wt. $\%$. Electrolyte $1 \mathrm{~mol} \mathrm{~L}^{-1} \mathrm{Na}_{2} \mathrm{SO}_{4}$; scan rate $2 \mathrm{mV} \mathrm{s}^{-1}$ (adapted from reference 6).

used only as positive electrode material, and is replaced at the negative electrode by activated carbon which is able to reversibly store hydrogen, as shown in the first section of this paper.

Figure 7 presents the voltammetry curves of the activated carbon ACP and of the $a-\mathrm{MnO}_{2} / \mathrm{CNTs}$ composite in $2 \mathrm{~mol} \mathrm{~L}^{-1} \mathrm{KNO}_{3}$, using a three electrode cell. The voltammogram of ACP shows that this material is perfectly adapted for a negative electrode, being able to be polarized down to $-0.85 \mathrm{~V}$ vs. NHE without di-hydrogen $\mathrm{H}_{2}$ evolution, whereas the thermodynamic value in this medium is $c a$. $-0.37 \mathrm{~V} v s$. NHE. In the same electrolytic medium, the manganese oxide composite is very attractive for the positive electrode because it can be polarized up to values higher than the electrochemical $\mathrm{O}_{2}$ evolution. Hence, a voltage of $2.2 \mathrm{~V}$ could theoretically be reached by combining ACP and $a-\mathrm{MnO}_{2} / \mathrm{CNTs}$ as negative and positive electrode, respectively.

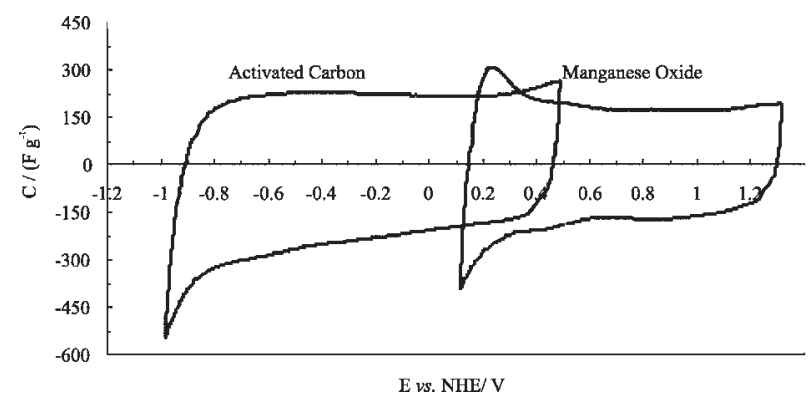

Figure 7. Cyclic voltammograms of activated carbon $\mathrm{ACP}$ and $a-\mathrm{MnO}_{2} /$ CNTs obtained with a three electrode cell in $2 \mathrm{~mol} \mathrm{~L}^{-1} \mathrm{KNO}_{3}$ aqueous electrolyte (adapted from reference 9).

Figure 8 shows the voltammograms of the hybrid capacitor realized by combining the two electrodes. According to the predictions, the curves present a boxlike shape, typical for a capacitor, up to a voltage of $2.2 \mathrm{~V}$.
However, using galvanostatic cycling, in order to be closer to the conditions of capacitor utilization, we have observed that the trend is out of linearity when the voltage is higher than $2 \mathrm{~V}$. This capacitance saturation is attributed to irreversible reactions at both electrodes, such as incomplete sorption of hydrogen at the negative electrode or di-oxygen evolution at the positive electrode.

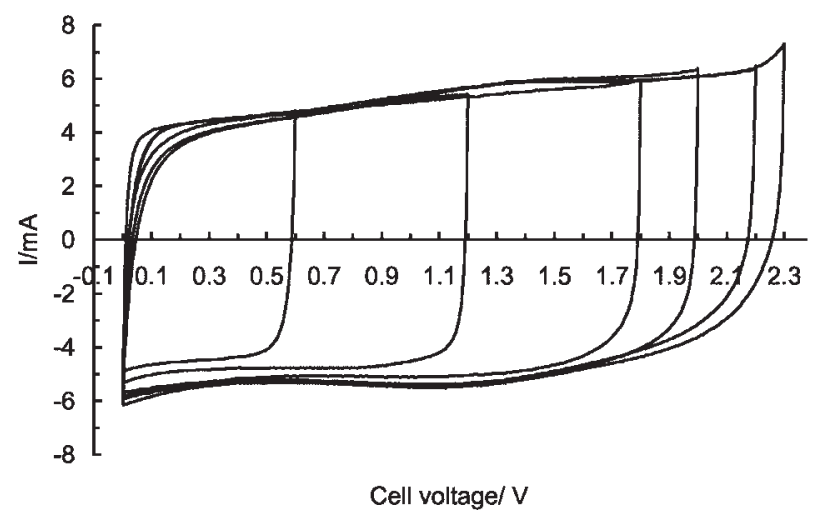

Figure 8. Cyclic voltammograms of the optimized asymmetric ACP/ $a-\mathrm{MnO}_{2}$ capacitor in 2 mol. $\mathrm{L}^{-1} \mathrm{KNO}_{3}$ electrolyte. Scan rate $10 \mathrm{mV} \mathrm{s} \mathrm{s}^{-1}$ (adapted from reference 9).

Due to its high capacitance and relatively high value of operating voltage, this capacitor can provide an energy density of $10.5 \mathrm{Wh} \mathrm{kg}^{-1}$, which is comparable to the values obtained with EDLCs operating in organic medium, without presenting the security hazards of these systems. Moreover, the power density reaches $123 \mathrm{~kW} \mathrm{~kg}^{-1}$, that can be attributed to the positive effect of nanotubes as conductivity additive in the $a-\mathrm{MnO}_{2} / \mathrm{CNTs}$ composite electrode.

\section{Conclusions}

This paper shows that, depending on their nanotexture, carbon materials may have different and very useful functions in electrochemical energy storage systems. Hydrogen can be stored reversibly at ambient conditions in the nanopores of activated carbons by electro-decomposition of water. The nascent hydrogen forms weak chemical bonds on the active sites present on the carbon surface. As a consequence of this relatively tight bonding of hydrogen, the charged material can be applied at ambient conditions as negative electrode of an electrochemical cell operating in aqueous medium. The nanotubes themselves are a perfect framework for electrode materials with pseudo-capacitive properties. They provide a good electrical conductivity to the resulting composite, a network of mesopores enhancing the diffusion of ions and a high resiliency during charge/discharge. As a consequence, electrodes could be realized from a cheap and 
environment friendly oxide such as $a-\mathrm{MnO}_{2}$. Combining the two electrode materials, i.e. the activated carbon for the negative electrode and the $a-\mathrm{MnO}_{2} / \mathrm{CNTs}$ composite for the positive electrode, allowed to build a system able to operate at $2 \mathrm{~V}$ in aqueous medium with a good cycleability. Hence, the example presented in this paper demonstrates that by an appropriate choice of carbon materials, high performance power sources can be developed.

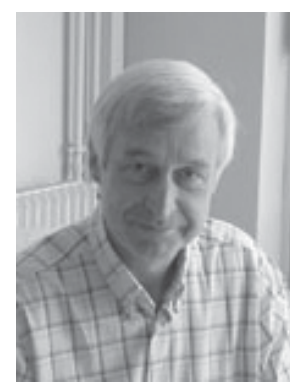

François Béguin is a specialist in chemical and Electrochemical applications of carbon materials. He develops synthesis processes of new nano-structured carbons together with a careful characterisation of their structural and micro textural properties by various techniques such as XPS, TEM, NMR, surface titration. He owns several patents related with the synthesis of nano-structured materials, in particular nanotubes, and their use for electrochemical systems. In the last years, he developed applications for lithium batteries, supercapacitors and hydrogen storage. He is President of the French Carbon Group (GFEC), member of the International Advisory Board of the Carbon Conferences, chairman of the Advisory Board for the International Symposium on Intercalation Compounds (ISIC).

\section{References}

1. Conway, B. E.; Electrochemical Supercapacitors - Scientific Fundamentals and Technological Applications, Kluwer Academic/ Plenum: New York, 1999.
2. Frackowiak, E.; Béguin, F.; Carbon 2001, 39, 937.

3. Laforgue, A.; Simon, P.; Sarrazin, C.; Fauvarque, J. F.; J. Power Sources 1999, 80, 142.

4. Khomenko, V.; Frackowiak, E.; Béguin, F.; Electrochim. Acta 2005, 50, 2499.

5. Brousse, T.; Toupin, M.; Bélanger, D.; J. Electrochem. Soc. 2004, 151, A614.

6. Raymundo-Piñero, E.; Khomenko, V.; Frackowiak, E.; Béguin, F.; J. Electrochem. Soc. 2005, 152, A229.

7. Frackowiak, E.; Lota, G.; Machnikowski, J.; Vix-Guterl, C.; Béguin, F.; Electrochim. Acta 2006, 51, 2209.

8. Béguin, F.; Szostak, K.; Frackowiak, E.; Adv. Mater. 2005, 17, 2380.

9. Khomenko, V.; Raymundo-Pinero, E.; Béguin, F.; J. Power Sources 2006, 153, 183.

10. Jurewicz, K.; Frackowiak, E.; Béguin, F.; Appl. Phys. 2004, A78, 981.

11. Ehrburger, P.; Dentzer, J.; Dziedzinl, P.; J. Anal. Appl. Pyrolysis 1993, 24, 333.

12. Lee, H. Y.; Goodenough, J. B.; J. Solid-State Chem. 1999, 144, 220.

13. Lee, H. Y.; Kim, S. W., Lee, H. Y.; Electrochem. Solid-State Lett. 2001, 4, A19.

14. Vix-Guterl, C.; Frackowiak, E.; Jurewicz, K.; Friebe, M.; Parmentier, J.; Béguin, F.; Carbon 2005, 43, 1293.

15. Béguin, F.; Friebe, M.; Jurewicz, K.; Vix-Guterl, C.; Dentzer, J.; Frackowiak, E.; Carbon 2006, 44, 2392.

16. Lillo-Ródenas, M.A. ; Cazorla-Amorós, D.; Linares-Solano, A.; Carbon 2003, 41, 267.

17. Hong, M.S.; Lee, S.H.; Kim, S.W.; Electrochem. Solid-State Lett. 2002, 5, A227.

Received: April 24, 2006 Published on the web: October 5, 2006 